\title{
CORPO E ESPAÇO: UMA REFLEXÃO DIALÉTICA ACERCA DO OBJETO DE ESTUDO DA GEOGRAFIA
}

\author{
BODY AND SPACE: A DIALECTIC REFLECTION ABOUT THE \\ GEOGRAPHY STUDY'S OBJECT
}

\section{CUERPO Y ESPACIO: UNA REFLEXIÓN DIALÉCTICA SOBRE EL OBJETO DEL ESTUDIO GEOGRÁFICO}

Guido Lins Lopes Bragioni ${ }^{1}$

Universidade Federal de Minas Gerais, Belo Horizonte, Brasil

Marina Araújo ${ }^{2}$

Universidade Federal de Minas Gerais, Belo Horizonte, Brasil

\begin{abstract}
Resumo: Este ensaio se propõe a refletir, através da arte, sobre o conceito de espaço e suas relações dialéticas com a paisagem, o território, o lugar e o corpo. Neste sentido, pensar as relações entre a Geografia e o corpo significa conceber que o espaço geográfico é constituído por uma materialidade animada, misturada e marcada nos corpos e, ao mesmo tempo, que esses corpos se aportam no espaço e no tempo, atravessados pelas intensidades com as quais experimentam o mundo.
\end{abstract}

Palavras-chave: Espaço; Paisagem; Território; Lugar, Corpo.

Abstract: This essay proposes to reflect, through the art, about the concept of space and their dialectic all relations with landscape, territory, place and body. In this sense, to think about the relations between Geography and the body means to conceive that the geographic space is constituted by an animated materiality, mixed and marked in the bodies and, at the same time, that these bodies bring the space and the time, crossed by the intensities which they experience the world.

Keywords: Space; Landscape; Territory; Place; Body.

Resumen: Este ensayo propone reflexionar, a través del arte, sobre el concepto de espacio y sus relaciones dialécticas con el paisaje, el territorio, el lugar y el cuerpo. En este sentido, pensar en las relaciones entre la geografía y el cuerpo significa concebir que el espacio geográfico es constituido por una materialidad animada, mezclada y marcada em los cuerpos y, al mismo tiempo, que estos cuerpos toman el espacio y el tiempo, atravesados por las intensidades de los cuerpos que experimentan el mundo.

Palabras Clave: Espacio; Paisaje; Territorio; Lugar; Cuerpo.

\footnotetext{
1 Graduando em Geografia pela Universidade Federal de Minas Gerais (UFMG), E-mail: guidolb13@hotmail.com

2 Gruaduanda em Geografia pela Universidade Federal de Minas Gerais (UFMG), E-mail: marinaaraujo84@gmail.com
} 


\section{INTRODUÇÃ̃o}

Figura 1 - Fotografia de algum lugar da Serra do Espinhaço Meridional, 2018.

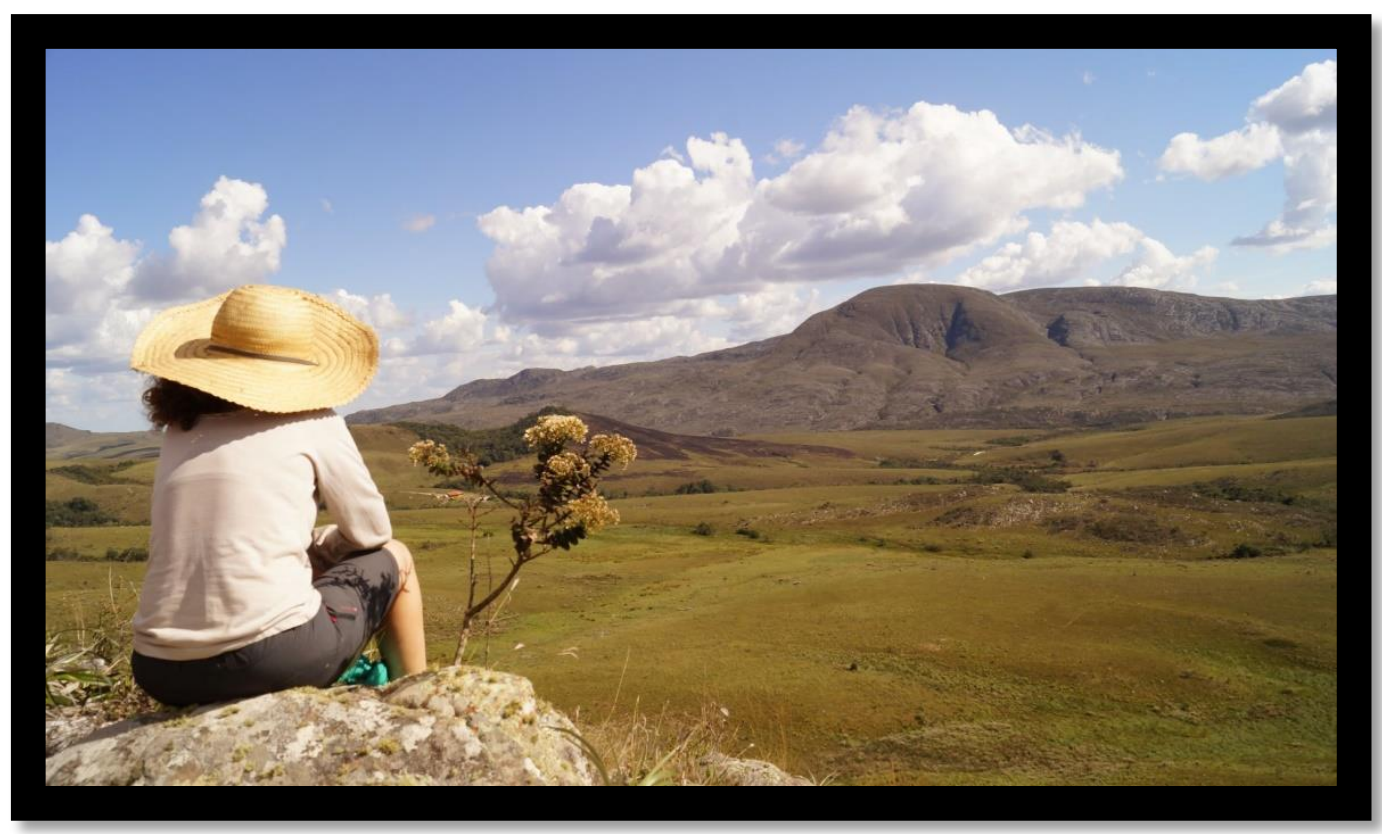

Fonte: Marina Araújo (2018)

Começamos este ensaio com uma fotografia, uma das formas das Belas Artes. Nela, há uma pessoa que contempla a paisagem e, por trás dela, uma lente que, impulsionada pela subjetividade do olhar da fotógrafa, capturou a imagem da observadora e da paisagem. Essa paisagem, objeto de estudo da Geografia, é o domínio do visível, corresponde a tudo aquilo que a visão abarca (SANTOS, 1988). Ela representa as formas, os conteúdos, os espaços, os lugares, os territórios e as relações entre os seres e o meio.

Seria possível identificar todas essas representações na fotografia (Figura 1)? Certamente, poderíamos compará-la a uma fotografia antiga tirada do mesmo lugar e, sem muito esforço, chegar à conclusão de que as paisagens mudam ao longo do tempo, de acordo com as lógicas de produção que nelas atuam em cada época. No entanto, os conteúdos, os espaços, os lugares, os territórios e as relações entre os seres e o meio não podem ser apreendidos somente pela observação de uma imagem. É preciso buscar, além do visível, a compreensão do invisível para um entendimento mais completo da 
Guido Lins Lopes Bragioni Marina Araújo
Geografia, Literatura e Arte, v.2, n.2, p. 49-64, jul./dez.2020

DOI: 10.11606/issn.2594-9632.geoliterart.2020.168193

paisagem e de toda sua aparência e essência, ou seja, a paisagem deve ser entendida em sua superficialidade, em sua forma e através sua natureza íntima (LEFEBVRE, 1947).

Sendo assim, a percepção provocada pela observação de uma fotografia não pode ser considerada conhecimento. Por meio dela, não conseguimos alcançar o significado da paisagem e todos os territórios, os lugares e o espaço que ela guarda. Alcançamos apenas a sua aparência. Além disso, a interpretação da paisagem é influenciada pela percepção de cada sujeito, ou seja, é um processo seletivo e subjetivo de apreensão (SANTOS, 1988), no qual cada pessoa a compreende de forma diferente.

Como buscar, então, o conhecimento da essência das paisagens? Um primeiro esforço seria o de conceber a existência de paisagens-lugares, paisagens-territórios, lugares-paisagens-territórios dentro do espaço, numa interação dialética que não permite sua delimitação precisa, mas que nos leva a pensar sobre as fronteiras existentes entre cada um desses conceitos.

Deste modo, pensar o espaço e suas complexidades significa refletir sobre os diversos contextos nos quais se situam diferentes relações socioculturais e políticas. Neste sentido, este espaço ultrapassa suas fronteiras físicas, atuando como palco de discussão e de construção de conceitos, de ideologias, de interdisciplinaridades e de leituras de mundo heterogêneas. Um verdadeiro híbrido que se relaciona entre si e entre outros híbridos.

Desta forma, as vivências de pessoas de distintas classes sociais, etnias, gêneros e papéis sociais, fluem através de fixos e constroem arranjos, complexidades e cenários diferentes. Consequentemente, nesse ápice, pessoas que se inserem dentro do meio natural, técnico-científico e informacional disputam territórios, compartilham lugares e vivem paisagens. Por isso, é possível pensar o espaço não somente pela relação sujeito/objeto, mas também pelos contatos entre sujeitos/sujeitos, e destes com seus próprios corpos.

Esta é, portanto, a reflexão central deste ensaio acadêmico, entendido como um texto utilizado para discutir determinado tema, de relevância teórica e científica (BARROS, 2011). A escrita de um ensaio tem como base teórica livros, revistas e artigos científicos e consiste na exposição das ideias e dos pontos de vista dos autores, buscando originalidade no enfoque, sem, contudo, explorar o tema de forma exaustiva (BARROS, 2011). 
Guido Lins Lopes Bragioni

Marina Araújo
Geografia, Literatura e Arte, v.2, n.2, p. 49-64, jul./dez.2020

DOI: 10.11606/issn.2594-9632.geoliterart.2020.168193

Sendo assim, este ensaio se propõe a refletir sobre o conceito de espaço e suas relações dialéticas com a paisagem, o território, o lugar, e o corpo. Nesse contexto, propõe-se um estudo no qual o espaço é entendido como um conjunto de fixos e de fluxos que o animam (SANTOS, 1988) e o corpo, como espaço-corpo (HISSA E NOGUEIRA, 2013).

\section{O ESPAÇO-CORPO}

Voltemos à fotografia que inspirou essa nossa discussão (Figura 1). Existiria espaço sem a presença daquela observadora e da fotógrafa que registrou a imagem? É possível concebermos uma paisagem sem a presença de um corpo-observador?

O espaço por si só, sem considerarmos o corpo que o permeia e o habita não existe. Ao mesmo tempo, o corpo não existiria sem o espaço, uma vez que ele faz parte das histórias dos lugares, dos territórios e das paisagens e pode ser retratado por diversas formas, incluindo a arte, como é o caso da fotografia.

Sendo assim, pensar as relações entre a Geografia e corpo significa conceber que o espaço geográfico é constituído por uma materialidade animada, misturada e marcada nos corpos e, ao mesmo tempo, que esses corpos se aportam no espaço e no tempo, atravessados pelas intensidades com as quais experimentam o mundo. Desta forma, é possível falar em "corpo-espaço" (o corpo no espaço), "espaço-corpo" (o espaço como parte do corpo) e no "corpo como espaço" (FERNANDEZ, 2015), em uma relação dialética, com suas formas, com a vida que os anima e com as transcorporalidades neles presentes.

Nesse sentido, as relações entre as espacialidades e as corporeidades esboçam os mais diversos cenários. Os corpos que fluem pelo espaço e que possuem distintas vivências, são capazes de influenciar movimentos cotidianos. Movimentos corpóreos que funcionam como metrônomos dos ritmos dos espaços (LEFEBVRE, 1947 apud NOGUEIRA 2013).

Desta forma, o movimento do corpo é um dos seus modos de ser no tempo e no espaço; é uma das manifestações da espacialidade e da arte. "O movimento é por definição particular, embora plural e diferenciado, perfazendo o jogo do uno e do múltiplo ao promover a distribuição e a localização dos corpos no espaço" (LIMA, 
Guido Lins Lopes Bragioni

Marina Araújo
Geografia, Literatura e Arte, v.2, n.2, p. 49-64, jul./dez.2020

DOI: 10.11606/issn.2594-9632.geoliterart.2020.168193

2007, p.68). O corpo pode ser entendido, então, como sinônimo de espaço praticado, "como o lugar de onde vemos o mundo" e "como o território de onde dizemos o mundo" (HISSA; NOGUEIRA, 2013, p.61).

Podemos falar, então, que há uma relação de reciprocidade na qual corpo e espaço/território/paisagem/lugar se implicam mutuamente. "Para um indivíduo não haveria espaço se ele próprio não fosse um corpo no mundo, ou seja, ele é no espaço" (LIMA, 2007, p.67).

Isto posto, toda experiência corporal é, por definição e princípio, uma experiência espacial e, assim, a Geografia determina ontologias implicadas em um mundo vivido: o mundo ambiente da existência cotidiana dos sujeitos. Desta forma, a Geografia não deve considerar apenas a natureza, mas toda a ligação dos homens com a terra, numa relação existencial que é, ao mesmo tempo, teórica, prática, afetiva, simbólica, interdisciplinar e com grandes contribuições do processo criativo e artístico e que delimita o que é um mundo (DARDEL, 2011).

\section{SOBRE OS FLUIDOS: A METAFÍSICA DA PAISAGEM}

O que é um mundo? Que relações se estabelecem entre os diferentes corpos e o espaço? Que visões de mundo esses corpos carregam consigo que fazem com que cada um deles tenha uma experiência diferente em relação à paisagem?

Pensemos nos viajantes naturalistas Humboldt e Saint-Hilaire e na observadora que está retratada na fotografia (Figura 1). Imaginemos que ambos estiveram naquele mesmo lugar onde se encontra a observadora, em tempos diferentes, em suas viagens pelo Brasil no século XIX e que fizeram um relato da paisagem observada por eles. Ora, uma mesma paisagem observada a partir de um mesmo ponto de observação geraria relatos semelhantes? Haveria a possibilidade de um olhar desinteressado, objetivo e científico dessa paisagem por parte dos viajantes?

Cada relato exprimirá recortes espaciais e temporais da realidade resultantes da escolha do objeto e da percepção de cada observador. O relato é uma conversação do corpo com o mundo e da ciência com a arte. Relatar é transcrever em arte aquilo que os olhos entendem como mundo. Logo, a paisagem não será a mesma para cada indivíduo. A interação com o espaço motiva relações interpessoais e intracorpóreas subjetivas por 
Guido Lins Lopes Bragioni Marina Araújo
Geografia, Literatura e Arte, v.2, n.2, p. 49-64, jul./dez.2020

DOI: 10.11606/issn.2594-9632.geoliterart.2020.168193

quem o observa e o vivência. Assim a geografia se expressa pela arte e pela movimentação dos corpos no espaço e do próprio corpo como processo de criação.

Concordamos com Marandola Jr. (2010), quando afirma que há geografias inscritas nas manifestações artísticas, da mesma forma que são necessárias geografias para concebê-las. Da mesma forma que a Ciência, a arte é feita a partir da relação orgânica dos seres humanos com o meio e, por isso, ela é importante para a Geografia:

(1) como relato documental, apegando-se à realidade retratada e àquilo que ela traz de facticidade histórico-geográfica; e (2) como imagem-imaginário ou símbolo-representação, que traz/produz uma visão de mundo (valores e símbolos),desenhando geografias e proporcionando a reflexão sobre a própria condição humana (MARANDOLA JR., 2010, p.9).

Sendo assim, as relações entre sujeito e conteúdo se dão de forma bastante específica, por meio de seu corpo subjetivo e de sua bagagem acumulada durante o seu percurso de vida. Pensar dessa forma, por exemplo, em um espaço-território, espaçolugar ou em um espaço-paisagem sem considerar as vivências humanas significa não conceber o espaço em sua essência.

Além disso, essas vivências não se destoam da presença do espaço-corpo. Todo esse contexto deve ser entendido para além da aparência de como as coisas se dão. Se olharmos para o mundo como aparência, ele demonstra existência de algo que não é aparência (ARENDT, 1993). Ao analisarmos o pensamento de Arendt (1993), é possível perceber que os objetos se exprimem além de suas próprias formas e perpassam questões que permeiam o nosso corpo e as suas relações corpóreas com a paisagem: a essência.

Nesse sentido, o corpo entende a paisagem e a paisagem se entrega ao corpo. Logo, a construção da paisagem vem de dentro de cada consciente e inconsciente onde a natureza íntima de cada paisagem é decifrada e compreendida de acordo com as experiências pessoais de cada corpo. A arte se faz a partir de uma geografia visceral e de relações corpo e mundo, assim como a fotografia elucidada neste ensaio.

Com isso, mesmo que a essência, por vezes, esteja vinculada à aparência, o modo como os objetos se figuram, expressam diferentes conotações para os diferentes corpos. A aparência, muito além se diversificar pelos olhos de quem a observa, se 
Guido Lins Lopes Bragioni

Marina Araújo
Geografia, Literatura e Arte, v.2, n.2, p. 49-64, jul./dez.2020

DOI: 10.11606/issn.2594-9632.geoliterart.2020.168193

exprime de acordo com as interioridades corporais do próprio ser que opera seus sentidos e sua existência sobre a forma. Por conseguinte, a estética assume características pessoais, frutos do corpo (físico, consciente e inconsciente) que a enxerga (LEFEBVRE, 1947).

Desta forma, assim como a fotografia apresentada no início deste ensaio (Figura 1), os relatos de viagem, os croquis e os desenhos das paisagens feitas pelos naturalistas, são representações de uma paisagem codificada culturalmente e que reflete experiências múltiplas, que vão muito além da moldura da objetividade. Ao contrário, a fotografia, os croquis e os desenhos, enquanto manifestações da arte, são veículos epistemológicos, parceiros de outros saberes na formação de um conhecimento espacial (MARQUEZ, 2009). Assim, tal qual o naturalista em seu relato, o fotógrafo seleciona situações e lugares, assim como julga os eventos como dignos ou não de serem fotografados a partir de suas vivências, de sua concepção de mundo e de seu olhar (NASCIMENTO; STEINKE, 2018).

Neste contexto, o sujeito movido pela aparência, por seus sentimentos e por sua razão, caminha em uma estrada de simpatias internas e externas. "Talvez nada surpreenda mais neste nosso mundo, no entanto, do que a infinita diversidade de suas aparências, compreendida pelo simples valor de entretenimento de suas visões, seus sons e seus odores" (ARENDT, 1993, p. 36).

E a leitura desses relatos, fotografias e croquis? Se pedíssemos para outra pessoa lê-los, sua interpretação corresponderia, exatamente, às intenções dos registros feitos por seus autores?

O antropólogo Melville Herskövits mostrou um dia a uma aborígene uma foto de seu filho. Ela foi incapaz de reconhecer a imagem até o antropólogo atrair sua atenção para os detalhes da foto (...). A fotografia não comunica qualquer mensagem para aquela mulher até que o antropólogo a descreva para ela. Uma proposta, como 'isto é uma mensagem' e 'isto está no lugar de seu filho', é necessária à leitura da foto. Uma transposição para a língua que torne explícitos os códigos que procedem à composição da foto é necessária para sua compreensão pelo aborígene (DUBOIS, 1994, p. 41-42).

Reafirma-se: fotografias, relatos, croquis, desenhos de paisagem são representações codificadas culturalmente. Sendo assim, por serem infinitas as visões e os sentimentos imprimidos pela paisagem em cada corpo, o cenário sem a presença dos olhares e das sensibilidades não poderia ser elucidado nem discutido. A paisagem existe 
Guido Lins Lopes Bragioni Marina Araújo
Geografia, Literatura e Arte, v.2, n.2, p. 49-64, jul./dez.2020

DOI: 10.11606/issn.2594-9632.geoliterart.2020.168193

porque existimos. Somos a consciência da natureza que existe, e por isso somos sentidos, somos aparência, somos arte e geografia além de sermos, consequentemente, espaço.

A típica associação da paisagem à superfície é mais do que o que se passa pelo raso. Na compreensão de seu conceito, o nosso corpo é também chave para exprimir a paisagem. A aparência, a manifestação e o "fenômeno", portanto, são aspectos da coisa, não a coisa inteira (LEFEBVRE, 1947). A aparência carece de essência e essa só se faz presente porque o universo existe. $\mathrm{O}$ universo da metafisica, dos sentimentos e da mente e, por consequência, o espaço humano. A essência se converte para a aparência e a coisa se converte para o fenômeno (LEFEBVRE, 1947). Nesse aspecto, os sentidos, os valores e o olhar se convertem para a paisagem e as formas que a compõem se transformam em um fenômeno que transgrede a sua aparência.

"Como o corpo, a pele, o sensível ou o empirismo, a paisagem se veste de trapos remendados. Frágil, tantas vezes perdida e há tanto tempo quanto o próprio paraíso, é reencontrada ou descoberta em farrapos. Pedaços daqui, vestígios de lugares" (SERRES, 2001, p. 253), territórios; espaço. Assim, a paisagem é composta por uma sobreposição de escritas realizadas em diferentes momentos da história e, por esse motivo, não pode ser considerada estática ou acabada, assim como o espaço.

\section{TERRITÓRIOS, LUGARES E CORPOS}

O espaço é aberto, inacabado, feito de texturas imateriais. Espaço é corpo, é pele, é chão, é espaço praticado. Neste sentido, para apreender o espaço-território e o espaço-lugar somos levados a aprimorar nossos olhares para as manifestações das socioespacialidades como marcas dos territórios, das territorialidades e dos lugares. Antes de tudo, deve-se enxergar o próprio corpo como espaço.

Neste sentido, "o território significa mais do que apenas a inclusão das condições materiais da ação nas circunstâncias do Homem, esta categoria eivada de pautas civilizatórias e tão presente na esfera jurídico-política e na legitimação do Estado moderno" (RIBEIRO, 2005, p.12458). Território é categoria mediadora de tempos, de intercâmbios entre gerações e conjunturas. 
Guido Lins Lopes Bragioni

Marina Araújo
Geografia, Literatura e Arte, v.2, n.2, p. 49-64, jul./dez.2020

DOI: 10.11606/issn.2594-9632.geoliterart.2020.168193

Assim, a leitura do território nos proporciona a compreensão das lutas de apropriação do espaço, "dos confrontos entre interesses, projetos e visões de mundo que constituem a densidade (espessura) da vida social" (RIBEIRO, 2005, p.12459). É, desta forma, linguagem que codifica representações sociais, universos simbólicos, valores e condições materiais de vida dos corpos no espaço.

Nesta concepção de território, é possível reconhecer territorialidades, ou seja, as diferentes formas de apropriação do território que tensamente coexistem num determinado tempo e num determinado lugar. Os lugares, neste contexto, podem ser entendidos como um intermédio entre o mundo e o indivíduo (MLINAR, 1990).

Cada lugar à sua maneira é, por essência, o mundo. O lugar traz à tona a relação dos movimentos socioespaciais cotidianos como forma de expressão das ações humanas e não ignora a conexão materialística de um homem ao outro.

Retomando-se a fotografia esboçada no início desta escrita (Figura 1), é possível enxergar um espaço, uma paisagem-lugar. $\mathrm{O}$ corpo que se submeteu às peculiaridades do espaço vivenciou relações diversas que, somadas à sua carga de memória emotiva, constroem em sua mente uma nova experiência e um novo aprendizado proporcionado pelo lugar e pela experiência do contato das formas com os conteúdos do espaço.

O lugar é produto das relações humanas, entre homens e natureza, tecido por relações sociais que se realizam no plano do vivido, o que garante a construção de uma rede de significados e sentidos que são tecidos pela história e cultura civilizadora produzindo a identidade, posto que é aí que o homem se reconhece porque é lugar da vida. $\mathrm{O}$ sujeito pertence ao lugar como este a ele, pois a produção do lugar liga-se indissociavelmente à produção de vida (CARLOS, 1996, p.29).

Outrossim, o lugar é uma construção que se dá pela sociedade. O que existe num lugar está em completa relação com os outros elementos desse lugar. "O que define o lugar é exatamente uma teia de objetos e ações com causa e efeito" (SANTOS, 1978, p. 97). E essa teia de objetos e ações se relaciona diretamente à experiência corporal, às resistências e às lutas sociais, onde o lugar se caracteriza como o espaço de reprodução da vida.

É fundamental, neste sentido, considerar o lugar como o palco dos acontecimentos cotidianos, em sua dimensão real, prática, sensível e concreta. Ele é, portanto, uma construção de relações sociais no espaço vivido que, por sua vez, possui 
Guido Lins Lopes Bragioni

Marina Araújo
Geografia, Literatura e Arte, v.2, n.2, p. 49-64, jul./dez.2020

DOI: 10.11606/issn.2594-9632.geoliterart.2020.168193

uma rede de significações e sentidos, tecidos pela história e cultura. O lugar tem usos e sentidos e, portanto, abarca a vida social, a identidade e o reconhecimento. O lugar, tampouco se distancia do corpo e da corporeidade. Lugar e corpo são marcas no espaço.

Assim, o conhecimento geográfico é inerente à leitura e à compreensão dos territórios e dos lugares cuja existência é mediada pelos corpos que também são territórios e lugares. Este saber se concretiza na realidade cotidiana dos corpos, na efetivação de políticas, nas intervenções urbanas, nas manifestações culturais, nos escritos literários, na diversidade.

\section{FRONTEIRAS INTERDISPLINARES: O ESPAÇO DA GEOGRAFIA}

Diversidade. Buscar uma definição dessa palavra ultrapassa qualquer barreira do entendimento das diferenças e das relações sociais. A diversidade está presente na produção do espaço e na dialética do concreto (LEFEBVRE, 1947) nas relações. O espaço em sua complexidade e em sua totalidade é fonte de pensamento e de reflexão sobre as fronteiras interdisciplinares, sociais e políticas.

Então, pensar o espaço "geográfico" significa, instintivamente, conceber diálogos entre os diversos saberes? Milton Santos nos convida a conceber o espaço geográfico como sinônimo de espaço banal, o espaço de todos, todo o espaço. "Trata-se do espaço de todos os homens, não importa suas diferenças; o espaço de todas as instituições, não importa a sua força; o espaço de todas as empresas, não importa o seu poder" (SANTOS, 2000, p.104); o espaço de todos os saberes, não importa quais.

Neste sentido, a matriz de um emaranhado de opções de estudos, grupos, diálogos, discussões, abordagens metodológicas disciplinares e, consequentemente, a produção do conhecimento, são postas, nesse cenário, não como subgrupos ou extratos sociais, mas como interfaces dialógicas que se exprimem através dos relacionamentos por meio das fronteiras. Tais fronteiras, inseridas em diversas categorias de análises, como espaço, paisagem, lugar e território, se intersectam e perpassam valores culturais, científicos e disciplinares.

Compartilhamos com Hissa (2002), o conceito de fronteira, entendida como uma demarcação imprecisa e vaga dos saberes acadêmicos, como um campo aberto de interseções onde é possível integrar, em vez de dividir e delimitar o pensamento. Sendo 
Guido Lins Lopes Bragioni

Marina Araújo
Geografia, Literatura e Arte, v.2, n.2, p. 49-64, jul./dez.2020

DOI: 10.11606/issn.2594-9632.geoliterart.2020.168193

assim, as fronteiras entre os diversos ramos do conhecimento trazem uma reflexão sobre a necessidade de superação da sobreposição de saberes e, sobretudo, do superdimensionamento das técnicas nas disciplinas acadêmicas. Afinal, é válido ressaltar que, no decorrer da história da ciência, foi necessária a especialização das ciências e a dissolução entre elas, mas de maneira alguma, essas ciências deixaram de se comunicar e de intercambiar ideias e conhecimentos.

Sabemos cada vez mais que as disciplinas se fecham e não se comunicam umas com as outras. Os fenômenos são cada vez mais fragmentados, e não se consegue conceber sua unidade. É por isso que se discute cada vez mais: "Façamos interdisciplinaridade". Mas a interdisciplinaridade controla tanto as disciplinas como a ONU controla as nações. Cada disciplina pretende primeiro fazer reconhecer sua soberania territorial, e, à custa de algumas magras trocas, as fronteiras confirmam-se em vez de se desmoronar (MORIN, 1999, p.135).

O que se deseja aqui ressaltar é o fenômeno multidimensional e não as disciplinas que selecionam e fragmentam a dimensão do fenômeno. A Geografia, neste sentido, torna-se teoricamente frágil quando adota uma posição parcial frente ao seu objeto - o espaço - e encontra abrigo nas fragmentações e dicotomias presentes em seu próprio campo de saber (SANTOS, 2000).

Observemos, novamente, a fotografia que nos inspira esse diálogo (Figura 1). Que disciplinas acadêmicas poderiam falar sobre aquela imagem? A Geografia, a Arte, a Biologia, a Filosofia, a Arqueologia, as Ciências Sociais, a História; todas elas constituem conhecimentos e práticas cuja categoria comum é o espaço. Podemos, assim, falar na plasticidade do espaço e do tempo (NOGUEIRA, 2013), na maleabilidade de um conceito que perpassa diversos campos do conhecimento, nas diversas fronteiras interdisciplinares que, juntas, contribuem para a compreensão de sua totalidade.

No entanto, como elucida Hissa (2002, p. 13), "não há Geografia sem a transgressão de suas próprias fronteiras, assim como não há qualquer outra disciplina na ausência da contínua ultrapassagem de seus próprios territórios, tão sonhados como rigidamente marcados”. Assim, não se pode conceber o espaço como objeto de estudos de uma ciência, apenas. Não é possível se pensar no espaço sem considerar que ele é feito de lugares, de territórios, de paisagens; que ele é formado por culturas, por corpos, 
Guido Lins Lopes Bragioni Marina Araújo
Geografia, Literatura e Arte, v.2, n.2, p. 49-64, jul./dez.2020

DOI: 10.11606/issn.2594-9632.geoliterart.2020.168193

por sensibilidades, por sociabilidades; que ele é animado por movimentos, por fluxos, por construções.

Sendo assim, sem tapar nossos olhos para a realidade das relações sociais e das transdisciplinaridades, os diálogos acontecem e ao invés de criarem-se linhas de limites, propõem-se regiões de fronteiras que conversam e proporcionam uma familiarização entre as diferentes vertentes e virtudes, criando e desenvolvendo notas, conhecimentos, novos debates e reflexões, sem abandonar ou apagar do real a pluralidade dos territórios construídos. Afinal, partindo do pressuposto das relações dos fixos com os fluxos, a noção das grandezas e diversidades do olhar e das vivências destoam-se para diferentes culturas (linguagens e percepções) que, consequentemente, se encontram em um espaço de fronteira que dialoga.

No espaço acadêmico, por conseguinte, esses elos transdisciplinares são recriados através das disciplinas e caracterizam o surgimento de novas faces e facetas do saber como por exemplo, a Etnogeografia, a Geografia da Dança, a Biogeografia e a Fitogeografia. O universo da ciência contemporânea vem se constituindo daí, através das fronteiras dos saberes e das interfaces de diálogos por meio do estudo do espaço. Mesmo que por ora, o conservadorismo se esboce de forma gritante, estratificando e fragmentando o espaço sem compreender as conversações internas e externas, as integrações dos saberes, dos territórios e dos lugares são preenchidos, seja por necessidade científica, seja por ações sociais ou pela própria natureza híbrida do espaço.

Voltemos à nossa fotografia inspiradora (Figura 1). O que aquela pessoa observa?

Focalizando a planície, os olhos percorrem as imagens, à procura de limites imediatos. (...) Esse é o limite eleito da planície: a colina que, dobrada sobre várias outras, impede a visão para além do muro natural de pedra. De onde se está, não há mais planície. (...) Não há limite. De fato, o limite eleito da planície é uma abstração. (...) Entretanto, o limite - aquele conjunto de colinas - não é tampouco obstáculo. É abstração do olhar. É inquietação da visão. Não é, jamais, limite: pode ser visto a partir de um ângulo novo (HISSA, 2002, p.23).

Podemos ver a partir de um ângulo novo. Podemos imaginar. E a imaginação nos permite transpor o visível, a aparência, o imediato em busca de novas respostas ou de novas interpretações sobre o espaço; sobre a Geografia. Nas palavras de Hissa (2002, 
Guido Lins Lopes Bragioni

Marina Araújo
Geografia, Literatura e Arte, v.2, n.2, p. 49-64, jul./dez.2020

DOI: 10.11606/issn.2594-9632.geoliterart.2020.168193

p.118), "a imaginação desempenha diversas funções fundamentais, entre as quais merecem ser salientadas a função crítica e a função criadora. Ambas constituem um processo único que se estende da produção científica à construção de todos os discursos".

Assim, a imaginação alimenta a ciência e a arte para o desenvolvimento de seus processos criativos; criação e arte são, portanto, indissociáveis. O conhecimento, então, não se encontra na fragmentação dos saberes, nem no cientificismo contemporâneo que se distancia da arte. Ao contrário, ele se encontra na relação que se estabelece entre a consciência e o mundo.

Desta forma, a arte que nos interessa não se resume a uma expressividade de apoio à Geografia, a uma forma de apresentação de informações e dados sobre o conhecimento geográfico. Diversamente, a arte deve ser concebida como um veículo epistemológico para a formação desse conhecimento espacial.

Por isso, iniciar este ensaio com uma fotografia (Figura 1), com uma das formas das Belas Artes, não foi uma ação desinteressada. O espaço, objeto de estudo da Geografia, está na fotografia, na dança, na literatura, no corpo; ao mesmo tempo, ele se encontra na biologia, na antropologia, na história, nas ciências sociais, nas fronteiras entre os diversos saberes. Assim, a epistemologia do saber geográfico não está no limite, mas na fronteira entre os campos de conhecimento. E para alcançá-la, é preciso imaginar e se aventurar em novos caminhos.

\section{CONSIDERAÇÕES FINAIS}

O objetivo deste ensaio foi refletir sobre o conceito de espaço que perpassa pela arte e mantém suas relações dialéticas com a paisagem, o território, o lugar e o corpo. Neste contexto, consideramos a Geografia como determinante de ontologias implicadas em um mundo vivido: o mundo ambiente da existência cotidiana dos homens. Desta forma, a Geografia não considera a natureza, mas a relação dos homens com a terra, numa relação existencial que é, ao mesmo tempo, teórica, prática, afetiva, simbólica, artística e que delimita o que é um mundo (DARDEL, 2011).

Neste sentido, mundo e lugar, é um par essencialmente inseparável: o lugar se relaciona às vivências individuais e coletivas a partir do contato com o seu entorno, 
Guido Lins Lopes Bragioni Marina Araújo
Geografia, Literatura e Arte, v.2, n.2, p. 49-64, jul./dez.2020

DOI: 10.11606/issn.2594-9632.geoliterart.2020.168193

como ilustrado pela fotografia no início deste artigo e toda a discussão do conceito de espaço-corpo que também pode ser representado pela arte fotográfica. Com isso, o mundo corresponde a um campo de relações estruturado a partir da polaridade entre o eu e o outro (HOLZER, 2012). Nesta perspectiva, a abrangência desses dois conceitos fomenta reflexões sobre as relações entre corpo e espaço e suas múltiplas articulações possíveis com os fenômenos sociais e históricos ainda que dentro da arte.

Percebe-se, então, que há uma relação de reciprocidade na qual corpo e espaço se implicam mutuamente. "Para um indivíduo não haveria espaço se ele próprio não fosse um corpo no mundo, ou seja, ele é no espaço" (LIMA, 2007, p.67). Por isso, afirmamos neste ensaio que toda experiência corporal é, por definição e princípio, uma experiência espacial.

Por fim, concebemos o espaço como aberto, inacabado, feito de texturas imateriais e tecido pela arte e por uma geografia que dialoga com saberes e sentimentos. Espaço é corpo, é pele, é chão, é espaço praticado. Neste sentido, para apreender o espaço-território e o espaço-lugar somos levados a aprimorar nossos olhares para as manifestações das socioespacialidades como marcas dos territórios, das territorialidades e dos lugares; e a transgredir os limites da ciência geográfica.

\section{REFERÊNCIAS}

ARENDT, Hannah. A vida do espírito. Rio de Janeiro: ReluméDumará, 1993, 392p.

BARROS, Kazue Saito Monteiro de. Réplica 1 - o que é um ensaio?Rev. adm. contemp., Curitiba, v. 15, n. 2, p. 333-337, abr.2011. Disponível em: http://www.scielo.br/scielo.php?script=sci_arttext\&pid=S1415-

65552011000200011\&lng=en\&nrm=iso. Acesso em: 24 ago 2020.

CARLOS, Ana Fani Alessandri. O Lugar no/do Mundo. São Paulo: Hucitec, 1996.

DARDEL, Eric. O Homem e a Terra: natureza da realidade geográfica. Tradução de Werther Holzer. São Paulo: Perspectiva, 2011. 159p.

DUBOIS, Philippe. O ato fotográfico e outros ensaios. Campinas: Papirus, 1994, 362p.

FERNANDEZ, Joana. Corpo geográfico: reflexões sobre comunicação do corpo e da dança afro-peruana. Temática, ano XI, n. 08, ago.2015, NAMID/UFPB, p.95-108. Disponível em <http://periodicos.ufpb.br/ojs2/index.php/tematica>. Acesso em: 15 out. 2017. 
Guido Lins Lopes Bragioni

Marina Araújo
Geografia, Literatura e Arte, v.2, n.2, p. 49-64, jul./dez.2020

DOI: 10.11606/issn.2594-9632.geoliterart.2020.168193

HISSA, Cássio. A mobilidade das fronteiras. Belo Horizonte. UFMG. 2002.

HISSA, Cássio E. Viana; NOGUEIRA, Maria Luísa Magalhães. Cidade-corpo. Revista $U F M G$, Belo Horizonte, v. 20, n. 1, p. 54-77, jan./jun. 2013.

LEFEBVRE, Henri. Lógica formal/lógica dialética. Rio de Janeiro: Civilização Brasileira, 1947.

LIMA, Elias Lopes de. Do corpo ao espaço: contribuições da obra de Maurice MerleauPonty à análise geográfica. GEOgraphia, ano IX, n.18, 2007, p.65-84. Disponível em: <http://www.geographia.uff.br/index.php/geographia/article/view/226> Acesso em 26 set. 2018.

MARANDOLA JR., Eduardo. Humanismo e arte para uma geografia do conhecimento. Geosul, Florianópolis, v.25, n.49, p.7-26, jan./jun., 2010. Disponível em: <https://periodicos.ufsc.br/index.php/geosul/article/view/15475> Acesso em 07 out. 2018.

MARQUEZ, Renata Moreira. Geografias portáteis [manuscrito]: arte e conhecimento espacial. 2009. 248f. Universidade Federal de Minas Gerais, Instituto de Geociências. Tese de Doutorado. UFMG, Belo Horizonte, 2009. Disponível em: http://www.bibliotecadigital.ufmg.br/dspace/bitstream/handle/1843/MPBB-

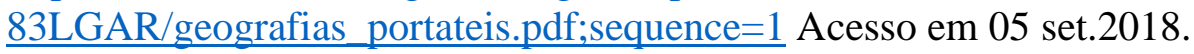

MLINAR, Zdravko. Identidades Territoriais: Entre o individualismo e a globalização. Globalização vs. Localização Instituto de Economia Espacial. Universidade de Warsaw, 1990.

MORIN, Edgar. Ciência com consciência. 3. ed. Rio de Janeiro: Bertrand Brasil, 1999, $135 \mathrm{p}$.

NASCIMENTO, Rafaela Araújo do; STEINKE, Valdir Adilson. Apontamentos teóricos para a relação entre paisagem e fotografia. $R$. Ra'e $G a /$ raega, Curitiba, v.44, p. 21-35, mai.2018.

NOGUEIRA, Maria Luísa Magalhaes. Espaço e subjetividade na cidade privatizada. 2013. 250f. Universidade Federal de Minas Gerais, Instituto de Geociências. Tese (doutorado). UFMG, Belo Horizonte, 2013.

RIBEIRO, Ana Clara Torres. Território usado e humanismo concreto: o mercado socialmente necessário. Anais do X Encontro de Geógrafos da América Latina - 20 a 26 de março de 2005, Universidade de São Paulo.

SANTOS, Milton. A natureza do espaço; técnica e tempo; razão e emoção. São Paulo: Hucitec, 1978.

SANTOS, Milton. Metamorfoses do espaço habitado, fundamentos teórico e metodológico da Geografia. São Paulo: Hucitec, 1988, 28p. 
Guido Lins Lopes Bragioni Marina Araújo
Geografia, Literatura e Arte, v.2, n.2, p. 49-64, jul./dez.2020

DOI: 10.11606/issn.2594-9632.geoliterart.2020.168193

SANTOS, Milton. O papel ativo da geografia: um manifesto. Revista Território: XII Encontro Nacional de Geógrafos. Florianópolis-SC, jul.2000, p. 103-109.

SERRES, Michel. Os cinco sentidos. Tradução de Eloá Jacobina. Rio de Janeiro: Bertrand Brasil, 2001. 364p.

Recebido em 29/03/2020.

Aceito em 14/09/2020.

Publicado em 07/11/2020. 